\title{
A Study on Critical Thinking Assessment System of College English Writing
}

\author{
Tian Dong ${ }^{1} \&$ Lu Yue ${ }^{2}$ \\ ${ }^{1}$ School of Foreign Languages, North China Electric Power University, Baoding, China \\ ${ }^{2}$ School of Foreign Languages, North China Electric Power University, Baoding, China \\ Correspondence: Tian Dong, School of Foreign Languages, North China Electric Power University, No.619, \\ Yonghua North Street, Baoding, Hebei Province, 071003 China. Tel: 1-370-322-4724. E-mail: \\ yuyanxue110@163.com
}

Received: September 17, 2015 Accepted: October 15, 2015 Online Published: October 16, 2015

doi:10.5539/elt.v8n11p176

URL: http://dx.doi.org/10.5539/elt.v8n11p176

\begin{abstract}
This research attempts to discuss the validity of introducing the evaluation of students' critical thinking skills (CTS) into the assessment system of college English writing through an empirical study. In this paper, 30 College English Test Band 4 (CET-4) writing samples were collected and analyzed. Students' CTS and the final scores of collected writing samples were respectively regarded as two independent variables to make a correlation analysis through Pearson Correlation of SPSS17.0 software. In addition, Excel was also used as an instrument to analyze the research results. The findings suggest that the two variables are significantly and positively correlated with each other, that is, students' CTS greatly influence their English writing proficiency. Thus, it is quite necessary to cultivate students' CTS to improve their English writing competence.
\end{abstract}

Keywords: critical thinking skills, assessment system of college English writing, empirical study

\section{Introduction}

In recent years, the fact that Chinese college students lack CTS is widely criticized by domestic scholars and Huang Yuanshen (1998) calls it "critical thinking absence disease", therefore the study on CTS has gradually become a hot issue. A group of scholars represented by Wen Qiufang have long devoted themselves to the construction of "hierarchy model" which is regarded as the assessment instrument of CTS in China. Meanwhile, theses which focus on CTS began to emerge. Lots of scholars have realized that it is increasingly important to combine foreign language teaching with pedagogy and pay more attention to cultivate students' CTS especially facing with the urgent need of innovative talents under the background of new era. College English writing is an intensive activity that requires high-level thinking, from thinking of a title to working out the framework, to writing and to revising. The whole process calls for critical thinking (Fang, 2013). However, the current domestic studies are mainly for English majors, which determines its limitations to some degree. Given this situation, this paper is designed to explore the correlation of college English writing proficiency and students' CTS on the basis of previous studies by analyzing 30 CET- 4 writing samples. The final purpose is to introduce the evaluation of CTS into the assessment system of college English writing and provide some suggestions for the reform of the assessment system of college English writing so as to enhance students' English writing competence.

\section{The Current Situation of Assessment System of College English Writing}

English writing is a high-level skill among the four basic skills in English learning and the writing competence is greatly influenced by students' CTS. However, on the one hand, the traditional teaching theories on college English writing put more emphasize on unifying a single pattern of the article structure. On the other hand, teachers tend to guide students to memorize the fixed composition templates and classic sentences, neglecting the inspiration of students' CTS during the process of writing. As a consequence, it is hard for students to write high-qualified compositions and put forward creative ideas. To be more specific, there are mainly three problems existing in college English writing teaching in China: Firstly, for a long time, English writing teaching in China 
lays particular stress on textual language skills training, including the analysis and imitation of the surface structure such as vocabulary, syntax and discourse, and ignores the cultivation of CTS. Secondly, many students regard correct grammar, beautiful words and neat structures as the standard of excellent writing thus neglecting the depth of thinking and inner logic of the writing content. Thirdly, college students generally lack logical thinking abilities such as analysis, comparison, synthesization, abstraction, generalization and classification as well as CTS.

Scholars at home and abroad have made some achievements in terms of the study on the assessment system of college English writing. However, the previous studies mainly aimed at changing the way of assessment from mono-assessment into multi-assessment (Chen, 2009). Some other scholars proposed that we should combine summative evaluation with formative evaluation (Zhang, 2009) but they barely did in-depth research although critical thinking has been mentioned in some aspects. As a result, there are still some problems in the current evaluation system of our college English writing mainly shown in three aspects: firstly, the form of evaluation is relatively unitary. Secondly, the assessment content is comparatively superficial. Thirdly, the assessment standard is fairly vague (Chen, 2009). Taking CET-4 writing samples as its corpus, this paper attempts to enrich the current evaluation system of college English writing by an empirical study and finally reaches the goal of providing a brand-new orientation for the reform of evaluation system.

\section{Literature Review of Critical Thinking at Home and Abroad}

\subsection{Definition}

Scholars at home and abroad (John, 1993; Scriven \& Paul, 1987; Salmon, 1989; Facione, 1990; Yeh, 2001; Geertsen, 2003; Paul \& Elder, 2006; Lin, 2006; Wen et al., 2009) have been exploring the connotation for the term "critical thinking" for years. After many discussions, a consensus is finally reached that the core elements of critical thinking can be summarized as these abilities such as analysis, synthesization, judgment, inference and evaluation.

\subsection{Research Status at Home and Abroad}

Wen Qiufang (2009) pointed out that in the past 20 years, western countries, especially America put more emphasis on the study of college students' CTS. Their studies can be roughly classified into three categories: (1) Define the subentry ability of CTS. (2) Construct the instrument to measure CTS. (3) Explore the way and the validity of cultivating CTS in higher education (Wen, Wang, Zhao, Liu, \& Wang, 2009). In this paper, the author concludes that two purposes are shown in the foreign researches on critical thinking. One is to construct the measuring tool for CTS, by which we can measure and check learner's CTS. Another purpose is to cultivate learners' CTS so as to improve their critical awareness and comprehensive qualities which require the integration of learning and reflection. In addition, Li Liwen (2011) also reviewed studies on critical thinking both at home and abroad and she summarized some influential theories such as double-dimensional model proposed by The Delphi Project, ternary thinking structure model constructed by Paul and Elder, Lin Chongde's the triangular thinking structure model as well as the most significant one named the critical thinking hierarchy theory model put forward by Professor Wen Qiufang. Among the above models, the critical thinking hierarchy theory model attracts more attention with its intuition and operability.

According to the critical thinking hierarchy theory model, CTS can be further divided into two dimensions: cognitive skills and critical thinking skills. Cognitive skills refers to the competence of planning, examining, regulating and evaluating one's own critical thinking. The second dimension emphasizes skills and standards associated to cognition as well as critical thinking disposition (see Table 1). This model is quite suitable for measuring college students' CTS because of its clear levels and straightforward evaluation standards. 
Table 1. Critical thinking hierarchy theory model (revised by Wen, 2008)

Cognitive Skills (Self-regulation ability)--the first level

CTS--the second level

\begin{tabular}{|c|c|c|}
\hline Cognition & & Personality Traits \\
\hline Skills & \multirow{6}{*}{$\begin{array}{l}\text { Standards } \\
\text { Clarity(clarity, precision) } \\
\text { Relevance(keep to the point, reasonably } \\
\text { detailed) } \\
\text { Logicality(coherent and reasonable) } \\
\text { Profoundity(with breadth and depth) } \\
\text { Flexibility(changing the point of view } \\
\text { quickly, using different CTS in } \\
\text { alternation freely ) }\end{array}$} & \multirow{2}{*}{$\begin{array}{l}\text { Curiosity(be willing to doubt, } \\
\text { ask and learn) }\end{array}$} \\
\hline Analysis(classification, & & \\
\hline $\begin{array}{l}\text { recognition, comparison, } \\
\text { clarification,discrimination, } \\
\text { internretation etc) }\end{array}$ & & $\begin{array}{l}\text { Openness(tolerate and respect } \\
\text { different ideas, be willing to } \\
\text { correct one's own views) }\end{array}$ \\
\hline $\begin{array}{l}\text { Inference(question, } \\
\text { reason, } \\
\text { demonstration ) }\end{array}$ & & $\begin{array}{l}\text { Confidence(believe one's own } \\
\text { judgment, dare to challenge the } \\
\text { authority) }\end{array}$ \\
\hline $\begin{array}{lc}\text { Evaluation(judging } & \text { of the } \\
\text { presupposition } & \text { assumption, }\end{array}$ & & $\begin{array}{l}\text { Integrity(pursue the truth and } \\
\text { justice) }\end{array}$ \\
\hline & & $\begin{array}{l}\text { Persistence(determined and } \\
\text { persistent, never give up easily) }\end{array}$ \\
\hline
\end{tabular}

English is a discipline with strong sense of humanity. In order to implement the policy of practicing quality education proposed by the government English teaching should pay more attention to guide students to think and cultivate their CTS rather than just staying on the level of practicing the four basic skills named listening, speaking, reading and writing. In recent years, scholars increasingly keep an eye on both theoretical and empirical studies on CTS of college students. Among them, the most prominent researches were conducted by research group led by Professor Wen Qiufang. They have done pioneering work to build up theoretical framework and instrument for measuring CTS of English majors. The instrument has been tested by 750 students from three universities in China, and it is still in the process of coming into being. Researches focusing on critical thinking by Tang Liping and Liu Wei, have yielded satisfactory results, also researches on post-graduates' CT ability in academic writing can be found. The famous scholars were Luo Qingxu (2000, 2001), Han Shaojie and Yi yan (2009), Zheng Yuqi (2010) etc. Most of these studies aim to introduce teaching pedagogy on critical writing like case studies and brainstorms, and few of them can combine cultivating CT with specific language classes, which make them absurd and unpractical. Therefore, the author suggests that it is quite necessary to combine CTS and its assessment with concrete courses like English writing to fill in the gaps of this field. This paper tries to integrate the measuring instrument of CTS into the assessment system of college English writing and finally construct a scientific and comprehensive assessment system. By doing so we can cultivate students' awareness of critical thinking in college English writing and enhance their CTS.

\section{Research Design}

The author selected 30 CET-4 writing samples (15 different topics) as the research object to analyze according to the critical thinking hierarchy theory model proposed by Wen Qiufang, which aims to demonstrate that students' CTS expressed in writings are closely related to the final scores. In order to perfect the current assessment system of college English writing we should definitely take CTS into consideration when we assess students' English writings. Because this initiative is expected to pave a new way for the reform of the assessment system of college English writing and consequently promote students' English writing proficiency.

\subsection{Research Questions}

This study aims to discuss the following 3 questions:

(1) What is the overall situation of students' CTS in the writing samples?

(2) Are there any significant distinctions from the perspective of the cognition and personality trait between high-score compositions and low-score compositions?

(3) Is there any relationship between the grade of CTS and the final scores of writings? If the answer is yes then how do they correlate to each other? 


\subsection{Research Object}

This study chose 15 different topics (each topic including two compositions of 8 points and 14 points) of CET-4 writing samples with a total number of 30 as the study object. The author will classify these writing samples and make a comparative analysis including the similarities and differences and then reach the conclusion.

\subsection{Research Instrument}

All of the writing samples used in this study are selected from CET-4 writing corpus, which has certain authority and universality. Furthermore, the situation of the writing part in CET-4 can reflect non-English majors' English writing competence in our country to some degree. What's more, the appraising procedures are relatively formal and on the other hand its scores are of higher reliability.

This study took SPSS17.0 software as its statistics and analysis tool. With this simple and practical software we can achieve the following functions such as statistical analysis, chart analysis, correlation analysis etc. Besides, the Excel will also be used to elaborate on the general situation of students' CTS.

\subsection{Research Procedures}

The author will analyze the selected writing samples according to the following steps:

(1) Briefly introduce the situation of the selected writing samples including the titles and the overall condition of students' CTS.

(2) Check the situation of students' CTS shown in the writing samples. The concrete procedures are to analyze students' cognitive abilities, namely whether students' writings meet the following requirements: clarity, relevance, logicality, profoundity and flexibility. As for personality traits, the author mainly focuses on curiosity, openness and confidence, because the last two items including integrity and persistence are less obvious to show in English writings. Therefore, the author mainly focuses on students' first three personality traits in this research. As for the assessment, we can adopt Likert's five-point scale to evaluate each item (5=very; 4=relatively; $3=$ basically; $2=$ not very; $1=$ very poor.) In this way we can get the scores of cognitive abilities and personality traits respectively and then add up the scores of the two sub-items to get the scores of students CTS in their writings. The higher scores indicate that the writer is equipped with strong CTS. On the contrary, the lower scores represent that the writers' CTS still need improving. Knowing the scores of students' CTS and the final grade of their writings, we can make a correlation analysis of the two variables to check out whether they are correlated to each other.

(3) Contrast 14 point compositions and 8 point compositions to find the differences and then summarize and come to the conclusion.

\section{Result Analysis}

Limited by space and time, the author can not list the analysis condition of the 30 writing sample one by one instead this study decided to choose 14 representative samples to illustrate. Table 2 answers the first two questions mentioned in research question part.

\subsection{The Overall Situation of CTS on Writing Samples}

As shown in Table 2, the selected 14 writing samples can be roughly classified into two types: the high-score group and the low one. Besides the final grade, their scores of CTS are also significantly different from each other. The overall scores for CTS of 14 points compositions are relatively high as well, they are respectively 28 points, 30 points, 30 points, 33 points, 31 points, 28 points and 29 points with the average score of 29.86 points. The inner difference in the high-score group is not very significant, which indicates the high reliability of the test. The situation of the low-score group is the opposite. The highest score in this group is 24 points followed by 20 points, 22 points, 22 points, 22 points, 20 points and 22 points with the average scores of 21.71 points. Given the above realities, we can reach two conclusions: first, the gap between average scores of the two groups is 8.15 points, which shows that besides some traditional factors such as grammar and sentence structure, their CTS are also significantly different from each other between high-score compositions and low ones. Second, scores of CTS in writing greatly influence the final grade of the compositions and they are positively correlated with each other. In order to demonstrate this conclusion, the author will use SPSS17.0 software to make a correlation analysis of these two variables and testify their positive relation. 
Table 2 Scores of students' CTS and final writing grades

\begin{tabular}{|c|c|c|c|c|c|c|c|c|c|c|c|}
\hline \multirow{3}{*}{ Titles } & \multirow{3}{*}{$\begin{array}{l}\text { Sample } \\
\text { No. }\end{array}$} & \multirow{3}{*}{$\begin{array}{l}\text { Final } \\
\text { Grade } \\
\text { (Points) }\end{array}$} & \multicolumn{8}{|c|}{ Sub-items of CTS } & \multirow{3}{*}{$\begin{array}{l}\text { Total } \\
\text { Scores } \\
\text { of CTS }\end{array}$} \\
\hline & & & \multicolumn{4}{|c|}{ Cognitive Ability (5 items) } & & \multicolumn{3}{|c|}{$\begin{array}{l}\text { Personality Trait (3 } \\
\text { items) }\end{array}$} & \\
\hline & & & $\stackrel{\circ}{\stackrel{2}{:}}$ & $\begin{array}{l}\frac{\overrightarrow{0}}{8} \\
2 \\
\stackrel{2}{2} \\
0 \\
0\end{array}$ & 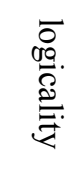 & $\frac{8}{\frac{8}{g}}$ & 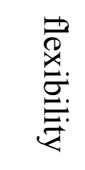 & 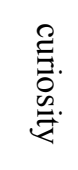 & 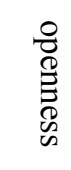 & $\begin{array}{l}8 \\
8 \\
0 \\
0 \\
0 \\
0 \\
0\end{array}$ & \\
\hline \multirow{2}{*}{$\begin{array}{l}\text { What } \\
\text { Electives to } \\
\text { Choose }\end{array}$} & No.1 & 14 & 5 & 4 & 4 & 3 & 3 & 2 & 3 & 4 & 28 \\
\hline & No.2 & 8 & 3 & 4 & 3 & 2 & 4 & 3 & 2 & 3 & 24 \\
\hline \multirow{2}{*}{$\begin{array}{l}\text { The Career I } \\
\text { Pursue }\end{array}$} & No.3 & 14 & 5 & 4 & 4 & 3 & 3 & 2 & 3 & 4 & 28 \\
\hline & No.4 & 8 & 3 & 4 & 3 & 2 & 4 & 3 & 2 & 3 & 24 \\
\hline \multirow{2}{*}{$\begin{array}{l}\text { Practice } \\
\text { Makes } \\
\text { Perfect }\end{array}$} & No.5 & 14 & 5 & 4 & 4 & 3 & 3 & 2 & 3 & 4 & 28 \\
\hline & No.6 & 8 & 3 & 4 & 3 & 2 & 4 & 3 & 2 & 3 & 24 \\
\hline \multirow{2}{*}{$\begin{array}{l}\text { Don't } \\
\text { Hesitate to } \\
\text { Say "No" }\end{array}$} & No.7 & 14 & 5 & 4 & 4 & 3 & 3 & 2 & 3 & 4 & 28 \\
\hline & No. 8 & 8 & 3 & 4 & 3 & 2 & 4 & 3 & 2 & 3 & 24 \\
\hline \multirow{2}{*}{$\begin{array}{l}\text { It Pays to Be } \\
\text { Honest }\end{array}$} & No.9 & 14 & 5 & 4 & 4 & 3 & 3 & 2 & 3 & 4 & 28 \\
\hline & No.10 & 8 & 3 & 4 & 3 & 2 & 4 & 3 & 2 & 3 & 24 \\
\hline $\begin{array}{l}\text { How to } \\
\text { Succeed in a } \\
\text { Job }\end{array}$ & No.11 & 14 & 5 & 4 & 4 & 3 & 3 & 2 & 3 & 4 & 28 \\
\hline Interview & No.12 & 8 & 3 & 4 & 3 & 2 & 4 & 3 & 2 & 3 & 24 \\
\hline $\begin{array}{lr}\text { How } & \text { I } \\
\text { Finance } & \text { My }\end{array}$ & No.13 & 14 & 5 & 4 & 4 & 3 & 3 & 2 & 3 & 4 & 28 \\
\hline $\begin{array}{l}\text { College } \\
\text { Education }\end{array}$ & No.14 & 8 & 3 & 4 & 3 & 2 & 4 & 3 & 2 & 3 & 24 \\
\hline
\end{tabular}

As shown in Table 2, the scores of personality trait which is the sub-item of CTS are generally in a low level. Among them, 7 points and 8 points are very common, even the highest score doesn't exceed 11 points. Therefore, it is safe to say that the scores of personality trait are generally low no matter in the high-score group or the low one, which may be something to do with students' own personalities and emotional qualities.

\subsection{Correlation Analysis of the Two Variables}

Both Table 3 and Figure 1 are used to answer the last question in the research question part, that is, to analyze the correlation of the two variables. The author regards scores of CTS and the final grade as two independent variables, and then uses SPSS17.0 to make a correlation analysis of the two variables. Firstly, input the data we get into the software editor. Secondly, check whether the two variables positively correlate with each other with Pearson correlation analysis.

\subsection{Test Result Analysis}

Figure 1 shows that the correlation coefficient between the two variables is $0.941>0.05$, which indicates that the 
two variables significantly correlate with each other under the condition of significant level being 0.01 . And they are positively correlated with each other, in other words, the students with high CTS will score a high mark in English writing. Therefore, it is quite necessary for teachers to take students' CTS into consideration when they evaluate their compositions, thus they can cultivate students' CTS and enhance their writing competence through the appraisal feedback.

Table 3. Correlation of students' writing scores and scores of CTS

\begin{tabular}{llll} 
& & $\mathrm{s} 1$ & $\mathrm{~s} 2$ \\
$\mathrm{~s} 1$ & Pearson Correlation & 1 & $.941^{* *}$ \\
& Sig. (2-tailed) & & .000 \\
& $\mathrm{~N}$ & 14 & 14 \\
\hline s2 & Pearson Correlation & $.941^{* *}$ & 1 \\
& Sig. (2-tailed) & .000 & 14 \\
& N & 14 &
\end{tabular}

**. Correlation is significant at the 0.01 level (2-tailed).

Note. $s 1=$ the final scores of writing; $2=$ scores of CTS.

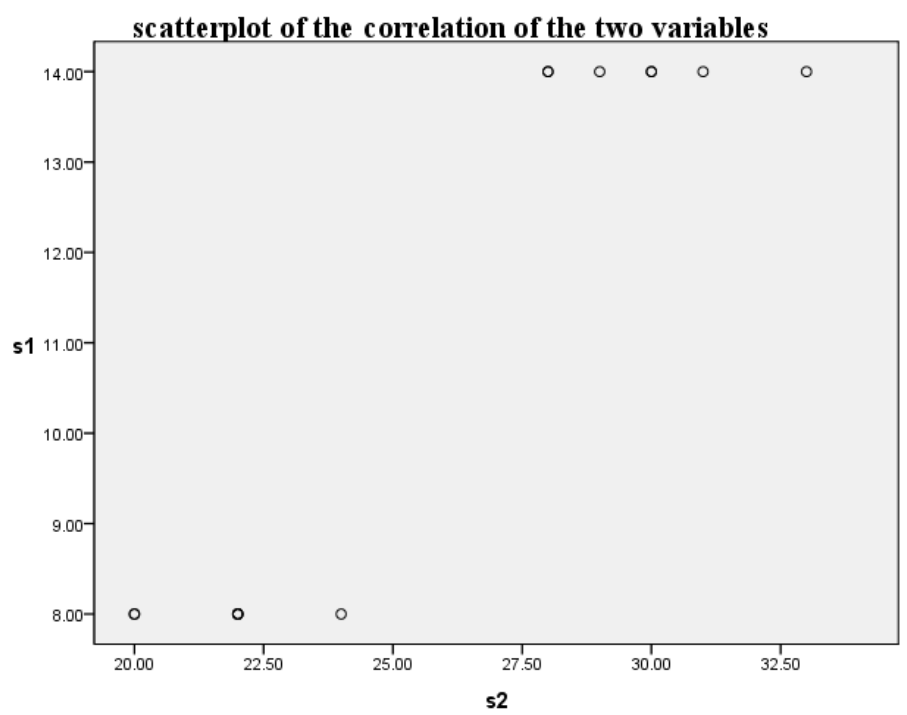

Figure 1. Scatterplot of the correlation of students' writing scores and scores of CTS

Note. $s 1=$ the final scores of writing; $\mathrm{s} 2=$ scores of CTS.

Figure 1 is a scatter diagram of the relationship between CTS and the final grade of the writing samples, from which we can see the positive correlation of the two variables more clearly. Thus, if we want to improve college students' writing skills we must attach great importance to the cultivation of their CTS and reform the current evaluation system of college English writing including the measures of strengthening the critical thinking element of the content and constructing clear standards for evaluating CTS.

\section{Conclusion}

Through the correlation analysis between scores of CTS and the final grade of writing samples, this study has demonstrated that the two independent variables significantly and positively correlate with each other. The result 
indicates that college students' CTS directly influence their English writing competence, which enables us to realize the necessity and urgency to strengthen students' CTS. This study is expected to mark a new direction for the reform of evaluation system of college English writing, that is, to integrate the assessment of CTS into the evaluation system of college English writing. Although the number of writing samples is limited and the conclusion needs further examination, the author firmly believes that the reform of the evaluation system of college English writing will definitely help to raise students' critical thinking awareness, strengthen their CTS and finally enhance their English writing competence.

\section{Acknowledgements}

The research is supported by Hebei Education Department Project (2014YYJG215).

\section{References}

Chen, A. M. (2009). A multi-perspective approach to the evaluation of English writing. Journal of Liaoninng Normal University, 32(6), 107.

Dewey, J. (1993). How we think. New York: D.C. Health and Company. http://dx.doi.org/10.1037/10903-000

Facione, P. (1990). California critical thinking skills test. Millbrae: The California Academic Press.

Fang, Y. Y. (2013). On the relationship between college students' critical thinking ability and their English writing, (Master's thesis, Yangzhou University, Yangzhou, China). Retrieved from http://epub.cnki.net/kns/brief/default_result.aspx

Geertsen, H. R. (2003). Rethinking thinking about higher-level thinking. Teaching Sociology, 31(1), 1-19. http://dx.doi.org/10.2307/3211421

Huang, Y. S. (1998). Absence of critical thinking. Foreign Language and Foreign Language Teaching, 7.

Huang, Y. S. (2010). The Curriculum for English majors must be reformed--discussion of absence of critical thinking once more. Foreign Language World, 1, 11-16.

Lin, C. D. (2006). A review of thinking psychology. Journal of Beijing Normal University, 5, 35-42. http://dx.doi.org/10.3969/j.issn.1002-0209.2006.05.009

Li, L. W. (2011). Research on English writing teaching and the cultivation of critical thinking skills. Beijing: Foreign Language Teaching and Research Press.

Salmon, M. H. (1989). Introduction to logic and critical thinking. Orlando: Harcourt Brace Jovanovich.

Scriven, M., \& Paul, R. (1996). Defining critical thinking: A draft statement for the National Council for Excellence in Critical Thinking. Retrieved August, 24, 2005.

Wen, Q. F., \& Liu, R. Q. (2006). An exploratory study on features in English major's abstract thinking in English argumentative compositions. Journal of Foreign Languages, 2, 49-58.

Wen, Q. F. Wang, J. Q. Zhao, C. R. Liu, Y. P., \& Wang, H. M. (2009). Constructing the theoretical framework of assessment instrument of critical thinking skills for college students in China. Foreign Language World, 1, $37-43$.

Yeh, S. S. (2001). Tests worth teaching to: Constructing state-mandated tests that emphasize critical thinkin. Educational Researcher, 30(9), 12-17. http://dx.doi.org/10.3102/0013189x030009012

Zhang, L. M. (2009). Applied research on diversified education evaluation system in English writing teaching. Journal of Shandong Institute of Trade Unions' Administration Carders, 109-110.

\section{Copyrights}

Copyright for this article is retained by the author(s), with first publication rights granted to the journal.

This is an open-access article distributed under the terms and conditions of the Creative Commons Attribution license (http://creativecommons.org/licenses/by/3.0/). 